Accepted Manuscript (AM) of Vullnetari, J. (2012) Women and migration in Albania: A view from the village. International Migration 5O(5): 169-188. [DOI: 10.1111/j.1468-

2435.2009.00569.x][accepted o8 September 2008; first published online 29 September 2009;

published 2012].

\title{
Women and Migration in Albania: A View from the Village
}

\author{
Julie Vullnetari*
}

\begin{abstract}
Since the fall of communism in the early 1990s, Albania has experienced migrations of epic proportions: 17 years later almost one in four Albanians has emigrated and lives abroad, primarily in Greece and Italy. Albanian emigration has by and large represented a typically male-dominated model, whereby men have 'led the way' and women have followed as family members. In spite of the considerable participation of Albanian women in this migration, their roles and experiences remain under-researched. Based on in-depth interviews with rural migrant women and their families, as well as additional ethnographic material collected during 2004-06 in Albania and Greece, this paper aims to contribute to filling this knowledge gap. The findings demonstrate the various ways in which Albanian rural women participate in the migratory process. They are often the most important pillar for supporting the family migration strategy through their productive and reproductive labour when remaining behind. They are also closely involved in decisionmaking about migration of other family members. Furthermore, they have been amongst the pioneers of the early 1990 migration themselves, including taking the long and risky journeys across the mountains to Greece. Overall, their contribution to the migrant household is beyond their presumed reproductive role and includes a strong economic component.

Whilst some 'traditional' norms and values persist and are reinforced during migration, change does take place, albeit at a slow and gradual pace. However, for the emancipatory benefits women could accrue through migration to be enhanced, immigration policies need adjusting to address their position as fully autonomous economic and social actors, thus reducing their dependency on male 'bread-winners'.

Albanian women's particular migratory experiences, combined with their increasing numbers as migrants, make a compelling case for further attention from researchers and policymakers.
\end{abstract}

Keywords: Albania, migration, post-communist women, gender

[The Version of Record of this manuscript has been published and is available in International Migration; published 2012; DOI: 10.1111/j.1468-2435.2009.00569.x]. * Sussex Centre for Migration Research, University of Sussex, Falmer, Brighton, BN1 9SJ, UK.
E-mail: < J.Vullnetari@sussex.ac.uk>, <jvullnetari@gmail.com>. 
Accepted Manuscript (AM) of Vullnetari, J. (2012) Women and migration in Albania: A view from the village. International Migration 5O(5): 169-188. [DOI: 10.1111/j.1468-

2435.2009.00569.x][accepted o8 September 2008; first published online 29 September 2009; published 2012].

\section{INTRODUCTION}

Since the demise of the communist regime in the early 1990s, Albania has witnessed an emigration of epic proportions: 17 years later around one million Albanians, or one quarter of the country's total population, have emigrated and are living abroad, primarily in Greece and Italy. Many Albanians also moved internally during this time, principally from rural to urban areas. Albanian emigration has, until recently, represented a typically male-dominated model, whereby men 'led the way' and women followed as family members. Although independent female emigration did take place, this was generally limited to women of professional background, and from urban areas, primarily from the capital Tirana. In spite of the considerable participation of Albanian women in migration, there has been a delayed inclusion of their roles and experiences in most scholarly research. This is however changing. Recent work, especially that which focuses on integration processes of immigrants in host societies, increasingly includes these experiences in their analysis (see for instance Hatziprokopiou 2006; King and Mai 2008; Vaiou and Stratigaki 2008).

Although the usefulness of a gendered approach which studies both men and women relationally is appreciated, this paper focuses on women alone. Its aims are threefold. First, to make visible the experiences of Albanian women engaged in migration processes, either as a family member staying behind, or as a migrant. Second, to explore the ways in which Albanian women participate in the migratory processes. Third, to explore some gendered relations which are perpetuated, challenged or transformed through Albanian migration.

The paper is structured as follows. The first section provides essential background on women's position in Albanian society, especially during communism and the post-communist transformation. This is followed by a review of key literature on Albanian migration, focusing specifically on women. The third section outlines the methodology used to collect the data on which this paper is based. The empirical core of the paper then follows, organised around women's experiences and participation in migration including decision-making, 
Accepted Manuscript (AM) of Vullnetari, J. (2012) Women and migration in Albania: A view from the village. International Migration 5O(5): 169-188. [DOI: 10.1111/j.1468-

2435.2009.00569.x][accepted o8 September 2008; first published online 29 September 2009; published 2012].

journeys, arrival and settlement. The final section draws conclusions and makes recommendations for policy, as well as for future research.

\section{WOMEN IN ALBANIA}

Albanian society has been described by anthropologists as strongly maledominated, where women become part of their husbands' family upon marriage and all inheritance follows the male line (Young 2000: 13). However, the degree to which these attributes apply to different parts of Albania and at different times varies. It is generally acknowledged that intra-family relations in the north of the country are very different from those in southern areas. Whilst patriarchal relations are still quite strong amongst northern communities, relatively more balanced and egalitarian relations have been developed in the south. This is the result of a long geo-historical and socio-cultural process, which is beyond the remit of this paper. However, it is necessary to mention here a few influencing factors.

Historically, the communities in the north were strongly organised around the large extended family, based on the clan structure (Whitaker 1981: 147). Within it, a very strict and clear hierarchy existed based on gender and age, according to which the father had unquestioned authority over his sons (and the rest of the family), the mother-in-law over her daughters-in-law, whilst women were subordinated to male supremacy (Halpern et al. 1996; see also Kera and Papa 2003). This was reinforced by the Code of Lekë Dukagjini, a set of customary laws and regulations that regulated all aspects of life in these northern, and very isolated, mountainous areas. The preservation of the family as a central pillar in an individual's life was due to its assumed multifunctionality, resulting from a weak penetration by other institutions such as the state, religious institutions, local lords etc. (Mitterauer 1996).

On the other hand, central and southern Albania became quite early on semifeudal, and, due to their geographical position, were more open to outside influences. More importantly, emigration took a hold in these areas and labour 
Accepted Manuscript (AM) of Vullnetari, J. (2012) Women and migration in Albania: A view from the village. International Migration 5O(5): 169-188. [DOI: 10.1111/j.1468-

2435.2009.00569.x][accepted o8 September 2008; first published online 29 September 2009; published 2012].

migrants travelled far and wide throughout the Ottoman Empire, and later on, in the early $20^{\text {th }}$ century, overseas to the Americas and Australia (Tirta 1999). This opened up avenues for outside influences and changes in the societal system, including the position of women.

Besides geographical differences, the temporal aspect needs to be taken into account. Although Zog's interwar government (1925-1939) introduced legislation aimed at equality between men and women, implementation failed (Musaj 2002; Whitaker 1981: 153). On the eve of World War Two, 90 percent of females countrywide were illiterate, the country had only 21 female teachers, and less than 3 percent of secondary school students were females (Hall 1994: 83; Logoreci 1977: 157-8).

Women's emancipation became a key aim of the post-war communist government. ${ }^{1}$ Although women's productive and reproductive roles were imposed in a top-down approach by the communist state, significant positive achievements did take place. The most important of these was the dramatic improvement in literacy rates and increased female participation in all levels of education. Indeed, in the 1980 s almost half of university students were female (Brunnbauer 2000: 152). Political participation also improved, albeit through allocated quotas. For instance, between 1970 and 1990, women constituted around 30 percent of the People's Assembly representatives, whereas their participation prior to 1945 had been nil (Lamani 2003: 25). Furthermore, women increasingly joined the labour force outside the home and by 1989 around 80 percent of working-age women were employed (Bezhani 2001: 2).

However, three issues of concern need emphasising at this point. First, the majority of women worked in what were regarded as female professions such as medical services, education, social welfare, as well as the textile and shoe industries, whilst rural economic employment was also highly gendered. Second, only few held high managerial positions. And third, paid employment was added to the work women continued to perform within the home. Thus, in spite of these efforts at emancipation, the roots of patriarchy in the private sphere were not 
Accepted Manuscript (AM) of Vullnetari, J. (2012) Women and migration in Albania: A view from the village. International Migration 5O(5): 169-188. [DOI: 10.1111/j.1468-

2435.2009.00569.x][accepted o8 September 2008; first published online 29 September 2009; published 2012].

fundamentally shaken. Although this situation was very similar to that of women in other Eastern-bloc countries (Brunnbauer 2000), the problems in Albania were exacerbated by the persistence of the concepts of honour and shame, which remained largely ingrained into the society. ${ }^{2}$ Some women like Musine Kokalari (founding member of the Social-Democratic party in 1946), who approached emancipation as independent thinkers, were shunted away in prisons and exile, whilst those who stayed in decision-making institutions largely followed the (communist) party line (Ekonomi et al. 2006a). Although the cadres of professional women had increased, by and large feminism and a conscious women's movement did not really emerge in Albania until the mid-1990s (Douglas 1994).

With the collapse of the communist regime, the supporting system of kindergartens and day-care nurseries that had been put in place to enable women to perform their role of the 'Heroic Worker', also crumbled. Some of their achievements gradually eroded, especially during the early years of the 1990s, amidst a power vacuum created by the dissolution of the previously omnipresent (communist) state. The "substitute social orders" that emerged were strongly based on the re-invention of tradition and the re-generation of patriarchy (Schwandner-Sievers 2006: 224). In the post-communist societies the position of women became precarious as they were the group most affected by the lack of personal security and economic opportunities. In addition, women's emancipation was stigmatised by association with the communist past and thus widely rejected (Brunnbauer 2000).

Consequently, women withdrew into the private domain where they were subject to other forms of insecurity, such as domestic violence. Although not unique to Albania, the greatest concern is that here it continues to be widely condoned by the law enforcement authorities and the wider public (Amnesty International 2006: 4, 13). According to Ekonomi et al. (2006b: 14), in Albania domestic violence is considered as "normal, as a means of education and a form of communication within the family". Many women are compelled to stay in 
Accepted Manuscript (AM) of Vullnetari, J. (2012) Women and migration in Albania: A view from the village. International Migration 5O(5): 169-188. [DOI: 10.1111/j.1468-

2435.2009.00569.x][accepted o8 September 2008; first published online 29 September 2009; published 2012].

abusive relationships because they lack economic opportunities, but also for the sake of their children and to preserve the 'honour' of their family (Amnesty International 2006; Minnesota Advocates for Human Rights 1996). These issues are compounded in rural areas (UNDP-Albania 2005: 78; Van Hook et al. 2000: 353).

Although women participate widely in education, their employment prospects are grim. Especially women with lower education levels, face exclusion and worse employment outcomes than men. Whilst three-quarters of working-age women (15-54) were in the labour force in 1991, by 2002 less than half of women in this age group were formally economically employed. For working-age men this indicator was reduced from 85 percent to slightly less than 75 percent over the same period of time (Moreno-Fontes Chammartin and Cantú-Bazaldúa 2003). Women also earn significantly less than men - about 68 percent of male wages on a monthly basis - both because they work fewer hours and because they earn less per hour (World Bank 2006). Most highly educated women continue to work in health and social care, education, the welfare services and mid-level managerial positions. Owning and running a business is even more difficult due to limited time to devote to business, curtailed freedom to travel, the risk of being exposed to (sexual) violence and lack of confidence in them by the society, including women themselves (Bezhani 2001: 4).

There are also significant differences between urban and rural women. Lower educated urban women work primarily in the few small-scale garment and shoe factories that exist. Their rural counterparts on the other hand are overwhelmingly employed in agriculture - almost 90 percent of those appearing in the labour statistics as employed in 2004 (World Bank 2006). Agriculture continues to be dominated by low-productivity subsistence farming, based primarily on the (often unpaid) labour of family members. Thus, whilst unemployment of women is high in urban areas, this is simply not an option for most rural families. 
Accepted Manuscript (AM) of Vullnetari, J. (2012) Women and migration in Albania: A view from the village. International Migration 5O(5): 169-188. [DOI: 10.1111/j.1468-

2435.2009.00569.x][accepted o8 September 2008; first published online 29 September 2009; published 2012].

Political participation and representation has suffered greatly since 1990, particularly as politics continue to display masculinist and at times violent features (Ekonomi et al. 2006a). In 2005, only 10 out of 140 elected members of parliament were women, whilst representation at local level was only 1 percent in the 2004 elections (Amnesty International 2006: 9).

Excluded from politics and from economic prospects in the public and private sectors, most professional women who did not emigrate turned to the NGO sector (UNDP-Albania 1999). However, being highly donor-dependent and less driven by issues and agendas at a local level, NGOs' representation of various groups of women, especially young and rural women, as well as the implications for the enhancement of women's socio-economic role generally, have been questioned (Sampson 1996; UNDP-Albania 2005: 115, 120). Whilst one can appreciate the 'third-wave' of feminism that Calloni (2002: 2) proclaims enthusiastically as the cooperation between Western and transition countries' feminists, the connection between urban and rural women within post-communist countries themselves has yet to materialise. By the late 1990 s the women's movement in Albania was practically non-existent in rural areas (UNDP-Albania 1999: 39); and by 2005, of the 100 registered women NGOs, only six focussed on rural women (UNDPAlbania 2005: 84). The presence of women's NGOs in rural areas is extremely limited, and is often initiated by foreign donors.

During the post-communist years, women's adverse situation was compounded by the large-scale emigration of men, particularly from rural areas. However, women also emigrated themselves. As INSTRAW (1994: 1) states, "[W]omen's migration [within and from developing countries] ... is inextricably linked to the situation and status of women in society". Indeed, from the above analysis we can conclude that women emigrated for a variety of reasons that reflected their position and status in Albanian society, including poverty, lack of economic opportunities, improvement of career prospects, personal advancement, being with their family, as well as in order to escape the constant surveillance of their local communities and the social consequences of practices 
Accepted Manuscript (AM) of Vullnetari, J. (2012) Women and migration in Albania: A view from the village. International Migration 5O(5): 169-188. [DOI: 10.1111/j.1468-

2435.2009.00569.x][accepted o8 September 2008; first published online 29 September 2009; published 2012].

related to 'honour' and 'shame'. Thus migration, combined with post-communist transformations, especially access to global communication, have brought significant changes in gender relations in Albania, especially amongst the younger generation and in urban areas. However, whilst emancipation has been the case for some women, emigration has reinforced 'traditional' gender roles for others, as will be shown later on in the paper.

\section{ALBANIAN WOMEN AS MIGRANTS}

Albania's history and tradition of migration was interrupted by 45 years of communist isolation, during which internal movements were highly regulated, whilst emigration was regarded as an act of treason punished by imprisonment and even death (for an in-depth historical account of Albanian migration see Vullnetari 2007). The country's violent exit from the communist years was accompanied, by large-scale international and internal migration. Albanian emigration presents a unique case not only in post-communist Europe but also more widely, by reason of its massive concentration over a short period of time and its specific features. Van Hear (1998: 119) has described it as "a new migration order", King (2005: 133) considers Albania as a "laboratory for the study of migration and development", whilst Carletto et al. (2006) talk about a "country on the move". Indeed, between 1989-2005 more than one million Albanians - a quarter of the country's population - were estimated to have emigrated and be living abroad, primarily in Greece $(600,000)$ and Italy (250,000), but increasingly in the USA $(150,000)$, the UK $(50,000)$ and other Western countries (Government of Albania 2005).

There has been a proliferation of studies on Albanian migration over recent years, particularly related to migrants in Greece and Italy, including a number of key analyses and theorisations such as Barjaba and King (2005), King (2003; 2005), King and Mai (2008), King and Vullnetari (2003). Very briefly, contemporary Albanian migration has involved three major episodes. The first, during 1990-93, was triggered by the violent and chaotic exit of the country from 
Accepted Manuscript (AM) of Vullnetari, J. (2012) Women and migration in Albania: A view from the village. International Migration 5O(5): 169-188. [DOI: 10.1111/j.1468-

2435.2009.00569.x][accepted o8 September 2008; first published online 29 September 2009; published 2012].

45 years of communist oppression, poverty, and almost hermetical closure to the outside world. The second intense movement followed the collapse of the dubious pyramid investment schemes in 1997 and the breakdown in law and order throughout the country, especially after the looting of the arms depots. And the third point refers to the migration influenced by the Kosovo crisis of 1999-2000 and the subsequent arrival of almost half a million refugees in Albania. Migration between these episodes and after 2000 has continued, albeit at a lesser pace.

The peculiar conditions of Albanian migration, particularly during the first two episodes, have led scholars to describe migrants as "economic refugees" (Barjaba 2000; Barjaba and King 2005), since the mixture of motivations for migration blurred the distinction between economic migrants and refugees. Over the years the typology of migration presented by Barjaba (2000) has evolved and diversified in terms of motivations, migrants' profiles, as well as migration trajectories and destination countries. The intensity observed during the $1990 \mathrm{~s}$ has diminished somewhat; migrants have increasingly regularised their status in host countries shifting thus from an irregular to a more regular situation; this in turn has helped replace much of the to-and-fro movements - especially to Greece - with permanent migration as well as a degree of transnationalism. In recent years family reunification and student migration have been on the increase, as well as highly skilled emigration and the migration of older people (King and Vullnetari 2006). As a result of this evolution and settlement in various countries, emerging transnational practices and embryonic diasporic communities have become reality for Albanian migrants as well (Mai 2005).

However, women's role and experiences in this migration remain underresearched. The course seems to be similar to that which the theories and literature on migration generally followed for many years, until a rebalancing started by Phizacklea's One Way Ticket (1983) - took place. Consequently, female migration, and gendered relations and processes in migration, have now become essential components of any multidimensional analysis. Some of the reasons for this prior neglect are applicable to the Albanian situation, such as the 
Accepted Manuscript (AM) of Vullnetari, J. (2012) Women and migration in Albania: A view from the village. International Migration 5O(5): 169-188. [DOI: 10.1111/j.1468-

2435.2009.00569.x][accepted o8 September 2008; first published online 29 September 2009; published 2012].

emphasis placed on economic motives, for which male migration is presumed to take precedence; “an underestimation of women's activity and labour force participation; a general neglect of women in [Albanian] scholarly social science research [besides issues of domestic violence and trafficking for prostitution];... and, in particular... inadequacies in existing data on women's migration" (INSTRAW 1994: xv).

Although Albanian migration started off as a typically male-led phenomenon, i.e. men migrated first and then women followed, its diversification in recent years has resulted in a more balanced picture. First, as a result of family reunification, both through clandestine migration and the regularisation of migrants in the two major destination countries, Albanian women now constitute more than 40 percent of Albanian migrants in Greece and Italy (BaldwinEdwards 2004: 5; King 2005). The prevalence of permits for family reunification amongst Albanian migrant women is indicative of the male-led model of migration to these countries (Bonifazi and Sabatino 2003). However, their economic contribution to the household needs to be taken into account. Second, migration to other destinations such as to the USA through the Diversity Visa Programme (known locally as the American lottery) has enabled more women to emigrate, particularly as principal applicants. And third, student and highly skilled migration have both involved considerable numbers of women, especially from urban areas, a number of whom have settled in North America (Orgocka 2005).

A distinct group often written about is that of women who participate in the sex industry. The problematic portrayal of the 'innocent, naïve, young, uneducated village girl, often of Roma ethnicity' is far from the reality of the complex continuum of age, education, social class, geographical background, consent for migration and participation in sex work etc. In most accounts these women are denied agency and infantilised by often being categorised together with children. In addition, incredulous claims of figures are damaging, especially since all sources accept the lack of reliable statistics and that multiplier effects are 
Accepted Manuscript (AM) of Vullnetari, J. (2012) Women and migration in Albania: A view from the village. International Migration 5O(5): 169-188. [DOI: 10.1111/j.1468-

2435.2009.00569.x][accepted o8 September 2008; first published online 29 September 2009; published 2012].

often used in calculations (UNDP-Albania 2005: 82). According to some such reports, the number of "trafficking slaves" by 1999 had reached 30,000, which means more than 10 percent of all Albanian female migrants around that time! 3 Furthermore, "entire villages and towns in Albania" are claimed to have been "robbed" of their young women (Van Hook et al. 2006: 30). Whilst exploitation and violence should be addressed at every stage, care should be taken that women's experiences, including those outside NGO shelters or police stations, benefit from multidimensional and dispassionate analyses (see for instance Campani 2000; Mai 2001; and for a more in-depth analysis Davies 2007).

In the highly gendered labour markets of Southern Europe, domestic work is a key sector of employment for migrant women, including Albanians. Campani (2000) argues that behind the demand in this specific sector of the economy stands the combination of, on the one hand, increased levels of professional mobility amongst local (Greek and Italian) women, and on the other the withdrawal of the welfare state from providing support to these women, especially for the care of the elderly and the children. However, as Campani and other scholars (Cavounidis 2006; King and Zontini 2000) emphasise, the welfare state has been considerably less developed in Southern Europe than in Northern European countries, especially regarding the provision of care, which has been traditionally provided within the family, primarily by women. As the latter have increasingly sought to move out of such reproductive tasks, this has been facilitated by the arrival of immigrant women, who have served as replacements in these roles (see also Vaiou and Stratigaki 2008 in the case of Greece). 4

Indeed, the Greek census of 2001 reported that more than half (52 percent) of Albanian migrant women in Greece worked in the census category "other" which includes mainly those working in domestic services as cleaners, hotel maids and carers of Greek elderly and children. The remaining half were employed in tourism (19 percent), agriculture (15 percent) and industry (9 percent) (BaldwinEdwards 2004). The situation in Italy very much reflects these patterns of 
Accepted Manuscript (AM) of Vullnetari, J. (2012) Women and migration in Albania: A view from the village. International Migration 5O(5): 169-188. [DOI: 10.1111/j.1468-

2435.2009.00569.x][accepted o8 September 2008; first published online 29 September 2009; published 2012].

employment in Greece; the majority of women are again employed in the domestic services sector (Bonifazi and Sabatino 2003).

Given the strength of the (patriarchal) family unit even in migration, women's earnings form part of the family income, which is often controlled by the men. This is particularly the case amongst migrants originating from northern Albania, as King et al. (2006) found for those who had emigrated from this area to the UK. According to their findings, women's earnings were pooled under the administration of their husband, and the money was then sent to his family in Albania, where it was again the male head of the household who received these remittances and overwhelmingly made decisions on their use. Although some changes were observed, by and large, the authors conclude that the "gendered geography of power" is enhanced during migration through the economic impact of remittances (emphasis in the original). For migrant women in Greece, Vaiou and Stratigaki (2008) argue that although the dominance of men in the family and their prime role in the migration project has remained the characterising feature of Albanian migrant families there, the very fact that women are earning their own income, which is at times more regular than men's, is empowering in itself.

Albanian women arriving in Italy and Greece were initially stereotyped, often as "prostitutes" (Zinn and Rivera 1995), the media being responsible for much of the hysteria around their presence. This image influenced their relations with the host communities and often justified their discrimination and marginalisation. In her study of Albanian and Filipino domestic workers in Greece, Lazaridis (2000) showed that Albanian women were amongst the most exploited groups in Greece. The double discrimination and marginalisation they suffered resulted from the deep-seated Greek xenophobia towards Albanians on the one hand, and the sexist and patriarchal gender relations that exist within Greek society itself, on the other. However, for some women change has taken place as they have used their agency and social capital to improve their position, as well as act as bridges in the 
Accepted Manuscript (AM) of Vullnetari, J. (2012) Women and migration in Albania: A view from the village. International Migration 5O(5): 169-188. [DOI: 10.1111/j.1468-

2435.2009.00569.x][accepted o8 September 2008; first published online 29 September 2009; published 2012].

incorporation of their families into the local neighbourhoods and communities (Vaiou and Stratigaki 2008).

Zinn and Rivera (1995) also conclude that the presence of women amongst Albanian migrants, especially in married couples, acted as an important regulator for relations with the Italian neighbours. Kelly (2005) emphasises that this improvement however is primarily observed in Albanian women's personal relations at the micro-level, whereas the public discourse seems to have been almost unaffected. The single and married women she interviewed in Bologna continued to face difficulties finding adequate housing and moving up the social ladder from jobs within the domestic services sector, even when they were highly educated. Generally, however, they experienced their migration to Italy as emancipatory. Dervishi's (2003) study of Albanian migrants in Italy also confirmed this, especially in relation to marrying an Italian partner. This intermarriage was perceived as emancipatory for women, but as "threatening the authority" of Albanian men. In contrast to these studies amongst, mostly, lower skilled migrant women in Europe, Orgocka (2005) showed that her highly-skilled respondents perceived discrimination from the US institutions as related more to their identity as migrants and as foreigners, than to their gender or to their specific Albanian ethnicity.

Although most migrant women are young and of working age, there is an increasing trend of "migrating grannies" (King and Vullnetari 2006). These are grandmothers who travel to provide childcare for their migrant sons' (and less often daughters') families, and transmit socio-cultural practices to the young generation. On the other hand, there is a risk of reduced provision of care for the fragile elderly left behind in Albania by their migrant family members - tradition often requires the youngest son and his wife to take care of his parents in old age - as the monetary benefits for Albanian young migrant women to care for elderly Greeks and Italians are much higher (Vullnetari and King 2008). Albanian women's incorporation into the global care chains is thus slowly becoming a 
Accepted Manuscript (AM) of Vullnetari, J. (2012) Women and migration in Albania: A view from the village. International Migration 5O(5): 169-188. [DOI: 10.1111/j.1468-

2435.2009.00569.x][accepted o8 September 2008; first published online 29 September 2009; published 2012].

reality (for more on global care chains see Ehrenreich and Hochschild 2003; and Hochschild 2001; and for the Albanian situation Vullnetari and King 2008).

\section{METHODOLOGY AND DATA}

This paper now proceeds with its first-hand analysis of women's role in Albanian migration by focusing on their perceptions and interpretation of their situations and experiences, thereby presenting a platform for their voices to be heard. It draws on empirical data collected for two projects: my MSc dissertation in 2003o4 which looked at the situation of elderly parents left behind by migrant children in rural south-east Albania; and my DPhil thesis in 2004-08 which examined the combined developmental impact of internal and international migration in Albania. Using a 'village outward' approach, I first interviewed migrants' families in their origin areas - a cluster of four villages in south-east Albania, and then followed the migrants in their destination places internally - in the capital Tirana and in the regional city of Korçë, and internationally - in the Greek city of Thessaloniki. The 160 in-depth interviews collected in this way were supplemented with participant observation in all four locations. This multi-sited approach was crucial in understanding migrants' lives within the context of the translocal and transnational family and the social spheres surrounding them (Levitt and Glick Schiller 2004: 1012-13; Vertovec 1999: 457).5

It proved difficult and impractical to interview an individual alone in rural areas, since other members of the family were present and often contributed with pieces of information. A number of interviews included both the husband and the wife. For this reason, the actual number of interviewees was higher than the number of interviews. Of the total of 210 respondents, 103 were women divided by location as follows: 71 women in the villages (including a few returnees, seasonal migrants and transnational grandmothers), 18 women in Tirana, four women in Korçë and 10 women in Thessaloniki. The analysis presented here draws on all this empirical material. However, because I specifically address the issue of international migration in this paper, the focus is on life in the village and 
Accepted Manuscript (AM) of Vullnetari, J. (2012) Women and migration in Albania: A view from the village. International Migration 5O(5): 169-188. [DOI: 10.1111/j.1468-

2435.2009.00569.x][accepted o8 September 2008; first published online 29 September 2009; published 2012].

the migratory situation in Greece. Interview excerpts have been chosen with this focus in mind.

In situations where more than one person participated in the interview, there was a tendency for the man to dominate the conversation, although not as prevalent as has been reported in other studies involving migrants from northern Albania (see for instance King et al. 2003). In fact, there were occasions in my fieldwork where the woman took complete control of the interview and left very limited space for her husband to speak out. In both situations, I used probing questions to open up opportunities for those less heard to have their say. On the other hand, interviews with migrants in their urban internal and international locations included more one-to-one conversations. In addition, being an Albanian migrant woman myself and employing empathy with the interviewees, made it possible to interview women alone without problems. Recorded interviews were transcribed and translated into English.

\section{MIGRATION FROM RURAL AREAS}

Participation of Albanian women in the migration process takes various forms from support of the residual household in Albania, decision-making about family members' migration, to migrating themselves and working abroad. Let us now look at each of these aspects in turn.

\section{Part of (residual) family}

Women in the literature on Albanian migration have been often portrayed as having a passive role in the migratory process. However, a more complex and nuanced situation is often the case. First, women are involved through their support to the migration project as a family strategy, often being the main pillar on which most household responsibilities rest, after their male relatives emigrate. In addition to looking after the household and working in the fields, they will support their migrant children by providing care for the left-behind grandchildren. Middle-aged women in their 50s and 6os may have to look after 
Accepted Manuscript (AM) of Vullnetari, J. (2012) Women and migration in Albania: A view from the village. International Migration 5O(5): 169-188. [DOI: 10.1111/j.1468-

2435.2009.00569.x][accepted o8 September 2008; first published online 29 September 2009; published 2012].

their older parents-in-law in their 70 s and 80 s as well as the young children of their migrant sons and sometimes daughters. The case of Lule illustrates this very well.

Lule is in her early 50 s and lives in rural Albania with her 80-year old motherin-law, two granddaughters of four and two and her son aged 16. Her husband works as a migrant in Veria, north-western Greece, and comes home only once every few months, especially when there is intensive farm work to be done in the village. Their eldest son and his wife live near Athens and have left their two young daughters in Albania, freeing the wife to undertake paid employment. The youngest son is not interested in helping with the household chores, as this is not what men are supposed to do; like most Albanian rural youth he is looking for a way out of farm work, often a chance to emigrate. This leaves Lule to shoulder all the everyday work around the house, such as cooking, washing and cleaning, as well as looking after the family cow, work in farming, looking after the two young granddaughters and, when her mother-in-law is unwell, looking after her too. Calling her a 'heroine', as in communist times, would not be an exaggeration. Thus, her contribution to the family's income-generating strategy through the reproductive (care) as well as productive (farming) work is crucial and indispensable. She represents an all-too-common scenario in contemporary rural Albania.

Second, women are also actively engaged in the migration decision-making process, as the following two examples show. In this context, it is important to bring age and marital status into the analysis. Older married women have a more influential position in the Albanian family than younger married and single women. Nicholson (2004) argues that marriage can lead to empowerment. However, this process requires many years of hardship, at times including endurance of abuse and violence, as mentioned earlier in the paper. Emigration of young single women from these rural areas, unaccompanied by other family members, continues to be frowned upon, unless it is for educational purposes. ${ }^{6} \mathrm{In}$ order to avoid bringing the family into disrepute, often parents insist that 
Accepted Manuscript (AM) of Vullnetari, J. (2012) Women and migration in Albania: A view from the village. International Migration 5O(5): 169-188. [DOI: 10.1111/j.1468-

2435.2009.00569.x][accepted o8 September 2008; first published online 29 September 2009; published 2012].

daughters get married before they leave, passing them from their tutelage to that of their husbands. Whilst talking to me about her daughter's migration, Adelina, 54, expressed her satisfaction that she was proud to have married off her daughters and sent them off to emigrate in the "proper" way, with their husbands, as they should. Although highly educated, the daughters seem to have accepted their mother's decisions, even though they had a chance to emigrate independently as they were the principal applicants for the US Green Card lottery.

... the eldest, was studying marketing. She continued for two years before winning the lottery for America... I then got her engaged, and then married and she left [with her husband]... After three years the youngest went there... [In Albania] she had entered two competitions to study management and nursing and she won both. However, I insisted that she study nursing, because it is for women [female occupation] and I liked it very much. My daughter listened to me... She was in her last year and had probably three months of traineeship left, when she won the [US Green Card] lottery. Because she wanted to leave, I got her engaged and then she left with her husband.

Whilst migration to the USA through such regular channels remains a dream for many young Albanian women, others' migratory route was to be closer to home, towards neighbouring Greece, and under less envious circumstances.

\section{The journey}

The literature on Albanian migration often depicts the difficult and dangerous journeys of male migrants, walking over the mountains to Greece or crossing the Otranto Strait by rubber boats to Italy. Although men were indeed in the majority to emigrate this way, the experiences of those women who undertook such 
Accepted Manuscript (AM) of Vullnetari, J. (2012) Women and migration in Albania: A view from the village. International Migration 5O(5): 169-188. [DOI: 10.1111/j.1468-

2435.2009.00569.x][accepted o8 September 2008; first published online 29 September 2009; published 2012].

journeys are often overlooked. The following two illustrative examples reveal that, although accompanied by male relatives throughout the journey, women took enormous risks travelling, at times even during late pregnancy and also with very young children. The first is the case of Eleni, of mixed Albanian and Greek parentage, who walked over the mountains to Greece in search of her long-lost Greek relatives in the city of Thessaloniki (see also Sintès 2003).7 Unfortunately, she had passed away at the time of the interview, but this is how her niece reflects on those days:

In the beginning, it was my aunt who came here [in Thessaloniki]. You know that her mother was from here [Greek]... It must have been 1990-91. She was amongst the first [migrants to cross to Greece from this area of Albania], the wire fence was still along the border. She left with my brother... who was 13-14 at the time... and a guy from the village who knew the way... (Kristina, 33, migrant in Thessaloniki).

The second quote comes from Lira, 36, who also lives in Thessaloniki:

... that time I came here in July 1998. My husband left before me, by paying money. Then he worked so we could have enough money for me to go... I was told we had to walk for two hours... we started our journey... I was shivering. I knew what that meant, I had done it before. But now I had two children to take care of as well. My son was nine months and my daughter two years old. I started breastfeeding my son so that he wouldn't cry and he was like an angel... my brother-in-law [who was accompanying them just for the mountain crossing] was carrying my daughter. The young guide, who had our bags, was walking in front, me and my son after him, and my brother-in-law with my daughter at the back... We 
Accepted Manuscript (AM) of Vullnetari, J. (2012) Women and migration in Albania: A view from the village. International Migration 5O(5): 169-188. [DOI: 10.1111/j.1468-

2435.2009.00569.x][accepted o8 September 2008; first published online 29 September 2009; published 2012].

were told [to walk] two hours perhaps to give us courage, but we must have walked at least four hours... I walked fast like the lightning. I didn't feel my feet at all, over stones and cliffs... but I am sure that there are angels up there who protected us... my son slept all the way and didn't make a noise... when I entered the house [in a border village in Greece where she and her children were being sheltered that night], when the Greek woman opened the door, that's when he woke up and started crying... she and her husband then took us to meet Genci [her smuggler], who drove us all the way to Athens.

Other such testimonies from women migrants and their relatives showed how they took deliberate actions in spite of the dangers, in order to be with their family members and improve their life. Albanian patriarchy is certainly important in shaping such relations and actions, but women do carve out spaces for themselves and embrace opportunities which enable them to exercise agency.

Recently a trend of migrating grandmothers (King and Vullnetari 2006) has been on the increase as migrants regularise their stay in the host country and start their new families. In addition to joining family members, Albanian grandmothers' migration displays two important features, and very specific to the Albanian migratory context. First, they provide much-needed childcare, thus freeing the migrant wife to participate in paid employment, which often leads to an improved economic situation. Second, they are transmitters of the Albanian language and culture to the younger generations, sometimes the only such link children have with their cultures of origin. Adelina, whom we met earlier, also plans to emigrate and join her daughters' families for these very reasons. However, for other families such important generational links are made next to impossible, due to various obstacles visa regulations put in their way, as Burbuqe relates: 
Accepted Manuscript (AM) of Vullnetari, J. (2012) Women and migration in Albania: A view from the village. International Migration 5O(5): 169-188. [DOI: 10.1111/j.1468-

2435.2009.00569.x][accepted o8 September 2008; first published online 29 September 2009; published 2012].

... my grandson was born recently in Greece. I would have liked to have had him here now [in the village], or to be able to go there. To cherish him. When he is able to come here, he won't know who I am (Burbuqe, 63, mother of migrant sons).

\section{Arrival and settlement}

After the arrival in the host country, women will usually take on the roles they have played in Albania. However, whilst some features of these roles are reinforced, over time others change, albeit slowly. Circumstances created by migration as well as Albanian patriarchal relations are important factors in shaping such changes. The first remark to make at this point is related to the peculiar family organisation of Albanian migrants in the early 1990s and women's role therein. In these years, when the majority of migrants were single men, or had come to Greece without their wives and children, and in order to save money, migrant relatives and sometimes friends would share accommodation amongst themselves (see also Iosifides and King 1998). In such arrangements, the only woman in the group would stay at home to cook, clean, wash and shop for sometimes more than 10 people. The men would all go out to work - often in very physically demanding jobs and for long hours - and contribute towards the common budget. This situation went on for several years until other female family members - often wives - would arrive and the reunited couple would move out to a new place. Under these circumstances, the women had very limited opportunity and time to interact with local people, and thus learn the language or enjoy other migratory benefits.

I have started part-time work now and will start full-time in September after the holidays. I have stayed at home all this time because I have had to look after many people, all our relatives and kin (Drita, 40, migrant in Thessaloniki). 
Accepted Manuscript (AM) of Vullnetari, J. (2012) Women and migration in Albania: A view from the village. International Migration 5O(5): 169-188. [DOI: 10.1111/j.1468-

2435.2009.00569.x][accepted o8 September 2008; first published online 29 September 2009; published 2012].

Where we lived before we only had one room... very small. Then we had relatives coming to stay with us and I would help them: a friend of my husband with his wife, they stayed two months, he worked and they returned to Albania. Then my maternal cousin and my husband's cousins, all in that small room... Then my brother and brother-in-law came to stay with us... but later my brother moved to another place because his wife will be joining him, whereas my brother-in-law was caught by the police as he had no papers and was returned to Albania... I couldn't change accommodation [during this time] because they would stay for two or three months and go. I would then have to pay the rent and everything for the rest of the year... (Edlira, 28, migrant in Thessaloniki).

This situation was characteristic of the 1990s, but it continues to take place, albeit on a smaller scale and involving perhaps one or two relatives.

The second observation is related to the difficulties women migrants face to hold on to regular employment, due to their role in the family as mothers-to-be and then as mothers. The majority of my female respondents in Greece were employed as cleaners, often in domestic situations, but sometimes for office complexes and cleaning the stairs of apartments; as day-carers for elderly Greeks; in catering such as fast-food outlets or restaurants where they have to work until the early hours of the morning; and in small garment factories. The findings reflect the general pattern amongst Albanian migrant women in Greece as revealed by the 2001 Greek census data, but also by other qualitative research (Baldwin-Edwards 2004; Hatziprokopiou 2006). Because most of this work is in the informal economy, they are rarely insured and often dependent on their husband's insurance for medical care or their staying permits. An additional problem is the lack of social security contributions towards the later years of their life: 
Accepted Manuscript (AM) of Vullnetari, J. (2012) Women and migration in Albania: A view from the village. International Migration 5O(5): 169-188. [DOI: 10.1111/j.1468-

2435.2009.00569.x][accepted o8 September 2008; first published online 29 September 2009; published 2012].

... of all [Albanian] women who work here [in Greece]... about 10 percent may have ensima [social security stamps], but the other 90 percent who work cleaning houses, do not (Zamira, 43, migrant in Thessaloniki).

Lack of insurance causes their exclusion from access to social benefits especially during childbearing and motherhood, such as paid maternity leave. Consequently, they find themselves having to pay informal fees (bribes) for their healthcare provision, which at times can seriously dent their wallets (Vaiou and Stratigaki 2008). The dependency on their male relatives increases around this time, as they are affected not only economically, but also regarding their status in the destination country, since a permit renewal is dependent on having a job, or in the case of the family reunification category, it is dependent on living with their husbands. As Zinn and Rivera (1995) argued in their research on Albanian women who emigrated to Italy in the early 1990s, "women may be penalized by their special conditions as child bearers because they are ignored by laws designed for a 'universal' male subject".

I have been here [in Greece] seven years... Both of my children were born here... I have not worked because I was on my own [in looking after the children]. In the beginning we had my husband's relative stay with us. So I stayed at home... I tried to find a job when I came here in the beginning, but I didn't speak the language. It was difficult... Then I decided to have a baby... When I was pregnant I used to be all day at home, I was unhappy, although when my husband and his cousin would come back from work we would go out. But the city was far from where we lived and we didn't have a car... when my son was three I found a job in a garment factory... and I paid an Albanian older woman to look after him for some 
Accepted Manuscript (AM) of Vullnetari, J. (2012) Women and migration in Albania: A view from the village. International Migration 5O(5): 169-188. [DOI: 10.1111/j.1468-

2435.2009.00569.x][accepted o8 September 2008; first published online 29 September 2009; published 2012].

hours... But then I became pregnant again and couldn't work there anymore [her job was to do the heavy ironing]... I had only worked there for two or three months and so couldn't get benefits... Then my daughter was born... I breastfed her for a year, where could I leave her? There are some [mothers] who sacrifice their children. I couldn't... so I haven't worked since then (Alma, 30, migrant in Thessaloniki).

The third aspect is that at times traditional gender relations may be exported and reinforced in the host country, but they are also challenged as well. At home it was usually the migrant women who did most of the chores, as well as looked after children's education even when they were working long hours. Women's work was often considered by men as less tiresome than their physically demanding jobs in construction or factories. At other times women worked fewer hours in order to have time to look after the household. In fact, Albanian women from the study area see these tasks as part of their identity and derive pride from performing them well. Part of a woman's self-esteem amongst peers and the wider community is her propriety and housekeeping skills. A significant part of this is, however, appearance, i.e. the aim in the first place is to influence and satisfy peers and community opinion. As such, living in more down-sized households in migration without the mother-in-law dictating everything within the home, as well as under less community scrutiny and surveillance, there is a sense of liberation amongst many women. Arjana, 35, who lives in Thessaloniki with her husband and their two children, explains why she enjoys the freedom she has as a woman in Thessaloniki as compared to Albania:

We discuss these issues amongst us when we are with other friends, couples. For instance the way a woman dresses. Perhaps she wears a short skirt... I am not talking about Tirana, because that is different [from the rest of Albania]. We always ask ourselves if 
Accepted Manuscript (AM) of Vullnetari, J. (2012) Women and migration in Albania: A view from the village. International Migration 5O(5): 169-188. [DOI: 10.1111/j.1468-

2435.2009.00569.x][accepted o8 September 2008; first published online 29 September 2009; published 2012].

our husbands would allow us to dress like this if we were living in Albania. Or if we would be able to go out like we do here... Even when we go there and our parents see the way we dress, my mother asks me: does your husband allow you to dress like this? The young teenage girls now are starting to dress like their peers here. But most women cannot go out at night like they do here, three or four friends going out to have an ice-cream, or taking their children for a walk... Husbands do not allow them in Albania. Something which we do every day here, with or without our husbands. Things are more limited there. We live here like them [the Greeks], something which we like.

Several interpretative remarks can be drawn from this quote. First, that Albanian migrant women in Greece have more time and space to enjoy the freedom of associating with their friends, not only at home but also in public spaces. This has also come as a result of their improved economic situation after years of living and working in Greece. Although some women have less financial opportunities and time to do this, generally there is a mentality that life should be enjoyed as well. Second, the husband's opinion remains important for these women even to the extent of (dis)approving the manner in which they dress. Thus, although there is change in migration, it is slow and far from fundamental. Third, it shows the complex generational change and continuity in Albania as the young teenage girls may dress like their peers in the West (read: Greece), whilst the older generations continue to observe 'traditional' norms and values and expect their migrant daughters to fully obey their husbands. Fourth, the intensity of changes depends on the geography, which highlights the large gap and cultural and socioeconomic polarisation between Tirana, the capital of Albania, and the rest of the country, especially rural areas. This is why most potential returnees intend to settle in Tirana upon their return, provided they have the financial means to afford its Western-like living costs. And finally, the quote shows how change is 
Accepted Manuscript (AM) of Vullnetari, J. (2012) Women and migration in Albania: A view from the village. International Migration 5O(5): 169-188. [DOI: 10.1111/j.1468-

2435.2009.00569.x][accepted o8 September 2008; first published online 29 September 2009; published 2012].

part of the incorporation process 8 of migrants into their host societies, which in this case reflects the adoption of host societies' norms and values related to gender roles. It must be remembered, however, that the Greek and Italian societies where the majority of Albanian migrants have settled, are themselves rather patriarchal and display unbalanced gender relations (Cavounidis 2004: 50-51; King and Zontini 2000). It is thus not surprising that the scale of change may not be that significant.

The final observation is related to women's role as bridges for migrants' incorporation into the host communities. Other research in Italy (Zinn and Rivera 1995) and Greece (Vaiou and Stratigaki 2008) has shown Albanian migrant women's key role for further incorporation of the entire family into the neighbourhood and wider host society through contact and interaction with local women. As mentioned earlier, the majority of Albanian migrant women work as domestic helpers, where their main contact point with the host society is often a local Greek or Italian woman. The domestic sphere thus becomes the arena where a number of relations are negotiated: between migrants and locals, between women of different ethnicities, age and class, but who might share similar gender-related positions within their own ethnic groups. Often these relations result in positive outcomes which enable further incorporation of migrant women and their families into the host society, particularly since the boundaries between the formal and personal in such work environments are often blurred.

My [female] employers are all in their late 40s and early 50s... They are all friends with each other. I started working for one, she recommended me to her friend, she in turn to her sister, she to her own friend and so on... They all have good jobs: hotel owner, warehouse and store owner, opera singer, bank officer etc... I have very good relations with them, especially the one I got to know first. Any problems or troubles I share with her... they all help me a lot (Edlira, 28, migrant in Thessaloniki). 
Accepted Manuscript (AM) of Vullnetari, J. (2012) Women and migration in Albania: A view from the village. International Migration 5O(5): 169-188. [DOI: 10.1111/j.1468-

2435.2009.00569.x][accepted o8 September 2008; first published online 29 September 2009; published 2012].

However, as Campani (2000) argues, these relations should be problematised and questioned, as they are often based on unequal and at times exploitative frameworks, where class and ethnicity play important roles.

\section{CONCLUSION}

Migration has been the defining feature of post-communist Albania, as hundreds of thousands of men and women have sought their fortunes abroad. In spite of significant female participation in this migration, women's migratory experiences remain under-researched. In this paper I have highlighted the importance of such inclusion into the relevant literature by drawing on previous research and presenting new empirical material. My findings show that Albanian women have participated widely in the migratory processes, through support for their migrant relatives when staying behind in Albania, and as migrants themselves. First, as their family members emigrate they are often the most important pillar for supporting the family migration strategy through their productive and reproductive labour when remaining behind. Second, they are closely involved in decision-making about migration of other family members. Third, they have been amongst the pioneers of the early 1990 s migration, including taking the long and risky journeys across the mountains to Greece. Fourth, upon arrival in Greece some norms and values that limit their autonomy persist, whilst change may be slow and gradual. Although mostly employed in domestic services, where relations with their local female employers are often shaped by exploitative frameworks that exist within the Greek society, they manage to carve out spaces as well as embrace opportunities to change their lives.

However, their efforts towards the improvement of their position and towards autonomy are negatively affected by the 'gender-biased' immigration regulations that regard men as principle 'bread-winners' and women as their family dependents. Most of these women have emigrated to Greece under the category of family reunification, as this is often the most practical way that allows them to 
Accepted Manuscript (AM) of Vullnetari, J. (2012) Women and migration in Albania: A view from the village. International Migration 5O(5): 169-188. [DOI: 10.1111/j.1468-

2435.2009.00569.x][accepted o8 September 2008; first published online 29 September 2009; published 2012].

be with their husband and children as a family unit in the host country. As a result of this type of legal status, their stay in the host country as well as their ability to access formal employment, social support and healthcare, are dependent upon their husband's situation: his paperwork, his formal employment and his ability to hold on to a long-term job. And not to forget, all is dependent on good relations between the husband and the wife, which is not always the case. It is thus clear that this situation of dependency does not facilitate women's autonomy and emancipation.

As I have shown in this paper, women's contribution to their migrant households reaches beyond the presumed reproductive role and as transmitters of cultural values. Therefore, immigration policy should be adjusted in order to reflect the strong economic role that migrant women play in migratory projects. It is time that this policy provided adequate provisions which consider women as independent migrants in their own right, by recognising their work and employment in the domestic sector as a category which can provide a basis for visas and staying permits. At the same time, measures should be taken in order to encourage employers, especially in the domestic sphere, to support migrant women's applications. This may be in the form of tax breaks for instance, or other such incentives. This suggestion may be understood as perpetuating the gendered labour market. However, it is unrealistic to ask more profound and far-reaching measures from a country such as Greece, with its poor record of immigration legislation and implementation where migrants continue to "remain "hostages" of a legal and institutional system which is too "sluggish" to respond (Kasimis and Papadopoulos 2005: 105). In addition, given the need for such services in an economy and society with an increasingly ageing population, poorly developed welfare state and higher participation rates of local women in formal employment, such a proposition might find more support amongst policymakers.

Yet, I emphasise that in order for women to benefit from the emancipatory effects of migration, more profound and far-reaching measures in immigration policy which ensure their autonomy and increase their agency, are essential. 
Accepted Manuscript (AM) of Vullnetari, J. (2012) Women and migration in Albania: A view from the village. International Migration 5O(5): 169-188. [DOI: 10.1111/j.1468-

2435.2009.00569.x][accepted o8 September 2008; first published online 29 September 2009; published 2012].

In this paper I have presented for the most part the experiences of Albanian migrant women of rural origin and overwhelmingly with lower educational levels. Therefore, these experiences cannot be generalised across Albania. Further research is thus needed to examine if, and how, these are different for urban women, especially of professional background, as well as women migrants in other destinations, where opportunities for personal freedom and advancement are much greater. In addition within the Albanian context, comparative research is needed between experiences of migrant women originating from the north and the south of the country, in order to understand the transformations and the elements that affect these groups. Finally, research which examines the experiences of migrant women from Albania and other post-socialist societies, would enrich our understanding of the specificities of the Albanian context. Finally, the importance of multidimensional analyses that include multiple categories of women's identity such as age, class, education and ethnicity, cannot be overemphasised.

\section{ACKNOWLEDGMENTS}

This paper is based on my doctoral research at the University of Sussex which was funded by the Economic and Social Research Council during 2004-07 [grant number: PTA-030-2004-00008], for which I am grateful. I would like to thank my DPhil supervisor, Prof. Russell King, both for his overall guidance of my ongoing work, and for his support with this paper. Thanks also to Ceri Oeppen and the participants of the DPhil migration seminar series at the University of Sussex, as well as to an anonymous referee for their valuable comments and insights. And last, but not least, I am grateful to all those women and men who shared their life stories with me and without whom this contribution would have not been possible. Any errors or omissions are entirely my own. 
Accepted Manuscript (AM) of Vullnetari, J. (2012) Women and migration in Albania: A view from the village. International Migration 5O(5): 169-188. [DOI: 10.1111/j.1468-

2435.2009.00569.x][accepted o8 September 2008; first published online 29 September 2009; published 2012].

\section{NOTES}

${ }^{1}$ Some scholars argue that women's emancipation in communist countries like Albania was not an end in itself, but a tool used by the government to facilitate its political goals (Brunnbauer 2000). However, as Logoreci (1977: 158) maintains, Albanian women should be given more credit and agency for demanding recognition of their rights in society, especially after they had massively participated alongside men in the communist resistance during the war.

2 These concepts relate specifically to the chastity of women. See also Tarifa (2007), for an indepth analysis of these concepts as related to social processes and norms in northern Albania.

3 Estimating Albanian emigrants abroad at 800,000 by 2000 (Barjaba 2000) and presuming that 40 percent of these are women.

4 Thank you to the anonymous referee for drawing my attention to the complexity of this issue.

5 The multi-sited approach has its roots in anthropology and migration studies (Hannerz 2003). Marcus (1995), who brought a clear conceptualisation of multi-sited ethnography in the late 1980 s, advocated this methodology as one which responds to the challenges of research in an increasingly globalised world, where multi-disciplinary and multi-method research are increasingly the case, by following the people, material things, ideas and processes in their movement. Especially useful for migration studies, this approach enables the researcher to capture a multitude of aspects of a migrant's life and thus come to a more holistic understanding of his/her experiences by including perspectives of, and dynamics in, both origin and the host location. As the French-Algerian sociologist Adelmalek Sayad who researched migration from Algeria to France has emphasised "before she or he becomes an immigrant, the migrant is always first an emigrant" (in Bourdieu and Wacquant 2000: 174; emphasis in the original).

${ }^{6}$ Education is highly regarded in Albania, including in the study area, and for young women in particular it is considered as a means to upward social and geographical mobility (see also Sjöberg 1992).

7 There is a significant ethnic-Greek community in Albania, living in the south and south-eastern districts along the Albanian-Greek border. The socio-economic and kinship relations that existed amongst inhabitants of these border areas suffered as the fall of the Ottoman Empire gave way to the new countries of Greece and Albania in the late $19^{\text {th }}$ and early $20^{\text {th }}$ century. Contacts were further limited during the almost 50 years of Cold War, only to resume in the early 1990s, as ethnic-Greek Albanians were amongst the first to emigrate to Greece. See also Hatziprokopiou (2006) for cross-border movements of ethnic-Greek Albanians from south-east Albania.

8 A concept which relates to the terms and conditions of entering and becoming part of the society (cf. Hatziprokopiou 2006).

\section{REFERENCES}

\section{Amnesty International (2006) Albania: Violence Against Women in the Family}

'It's Not Her Shame', Amnesty International, London.

Baldwin-Edwards, M. (2004) Statistical Data on Immigrants in Greece. An Analytic Study of Available Data and Recommendations for Conformity with European Union Standards, Mediterranean Migration Observatory, Athens. 
Accepted Manuscript (AM) of Vullnetari, J. (2012) Women and migration in Albania: A view from the village. International Migration 5O(5): 169-188. [DOI: 10.1111/j.1468-

2435.2009.00569.x][accepted o8 September 2008; first published online 29 September 2009;

published 2012].

Barjaba, K. (2000) "Contemporary patterns in Albanian emigration", South-East Europe Review, 3(2): 57-64.

Barjaba, K. and King, R. (2005) "Introducing and theorising Albanian migration", in King, R., et al. (eds), The New Albanian Migration, Sussex Academic Press, Brighton, 1-28.

Bezhani, M. (2001) Women Entrepreneurs in Albania, Small Enterprise Development (SEED) Working Paper 29, ILO, Geneva.

Bonifazi, C. and Sabatino, D. (2003) "Albanian migration to Italy: what official data and survey results can reveal", Journal of Ethnic and Migration Studies, 29(6): 967-95.

Bourdieu, P. and Wacquant, L. (2000) "The organic ethnologist of Algerian migration", Ethnography, 1(2): 173-82.

Brunnbauer, U. (2000) "From equality without democracy to democracy without equality? Women and transition in South-East Europe", South-East Europe Review, 3(3): 151-68.

Calloni, M. (2002) "Albanian women after socialism and the Balkan war", in Braidotti, R., et al. (eds), The Making of European Women's Studies, Utrecht University, Utrecht, 49-60.

Campani, G. (2000) "Immigrant women in southern Europe: social exclusion, domestic work and prostitution in Italy", in King, R., et al. (eds), Eldorado or Fortress? Migration in Southern Europe, Macmillan, London, 147-69.

Carletto, G., et al. (2006) "A country on the move: international migration in post-communist Albania", International Migration Review, 40(4): 76785.

Cavounidis, J. (2004) "Migration to Greece from the Balkans", South Eastern Europe Journal of Economics, 2(1): 35-59.

Cavounidis, J. (2006) "Labour market impact of migration: employment structures and the case of Greece", International Migration Review, 40(3): 635-60. 
Accepted Manuscript (AM) of Vullnetari, J. (2012) Women and migration in Albania: A view from the village. International Migration 5O(5): 169-188. [DOI: 10.1111/j.1468-

2435.2009.00569.x][accepted o8 September 2008; first published online 29 September 2009;

published 2012].

Davies, J. (2007) Understanding and Explaining Trafficking of Women from Albania to Lyon, France 1998-2001, DPhil thesis in Geography, University of Sussex, Brighton.

Dervishi, Z. (2003) Vështrime të Kryqëzuara në Det. Analizë Krahasuese Ndërmjet Kulturave Përmes Integrimit Sociokulturor të Emigrantëve Shqiptarë në Itali. Sociologji Kulture 1 (Gazing Over the Sea. Comparative Analysis Between Cultures Through the Socio-Cultural Integration of Albanian Migrants in Italy. Cultural Sociology 1), Jerusalem, Tirana.

Douglas, C. A. (1994) "Albania: feminism and postcommunism (Interview with Diana Çuli)", Off Our Backs: the Feminist NewsJournal.

Ehrenreich, B. and Hochschild, A. R. (2003) "Introduction", in Ehrenreich, B. and Hochschild, A. R. (eds), Global Women: Nannies, Maids and Sex Workers in the New Economy, Metropolitan Books, New York, 1-14.

Ekonomi, M., et al. (2006a) Representation and the Quality of Democracy in Albania. A Gender Perspective, Gender Alliance for Development, Tirana.

Ekonomi, M., et al. (2006b) Krijimi $i$ Mundësive Ekonomike për Gratë dhe Vajzat në Shqipëri: një Strategji për Parandalimin e Trafikimit. (The Creation of Economic Opportunities for Women and Girls in Albania. A Strategy for the Prevention of Trafficking), Aleanca Gjinore për Zhvillim, Tirana.

Government of Albania (2005) National Strategy on Migration, Government of Albania and IOM, Tirana.

Hall, D. (1994) Albania and the Albanians, Pinter, London.

Halpern, J., et al. (1996) "Patriarchy in the Balkans: temporal and cross-cultural approaches", The History of the Family, 1(4): 425-42.

Hannerz, U. (2003) "Being there ... and there ... and there ...! Reflections on multi-site ethnography", Ethnography, 4(2): 201-16. 
Accepted Manuscript (AM) of Vullnetari, J. (2012) Women and migration in Albania: A view from the village. International Migration 5O(5): 169-188. [DOI: 10.1111/j.1468-

2435.2009.00569.x][accepted o8 September 2008; first published online 29 September 2009;

published 2012].

Hatziprokopiou, P. (2006) Globalisation, Migration and Socio-Economic Change in Contemporary Greece: Processes of Social Incorporation of Balkan Immigrants in Thessaloniki, Amsterdam University Press, Amsterdam.

Hochschild, A. R. (2001) "Global care chains and emotional surplus value", in Hutton, W. and Giddens, A. (eds), On the Edge: Living with Global Capitalism, Vintage Books, London, 130-46.

INSTRAW (1994) The Migration of Women. Methodological Issues in the Measurement and Analysis of Internal and International Migration, UNINSTRAW, Santo Domingo.

Iosifides, T. and King, R. (1998) "Socio-spatial dynamics and exclusion of three immigrant groups in the Athens conurbation", South European Society and Politics, 3(3): 205-29.

Kasimis, C. and Papadopoulos, A.G. (2005) The multifunctional role of migrants in the Greek countryside: implications for the rural economy and society, Journal of Ethnic and Migration Studies, 31(1): 99-127.

Kelly, E. (2005) "Lifestyles and integration of Albanian women in Bologna. Two steps forward, one step back?", in King, R., et al. (eds), The New Albanian Migration, Sussex Academic Press, Brighton, 29-63.

Kera, G. and Papa, E. (2003) "Familja, feja dhe e drejta zakonore në Shqipëri deri në gjysmën e parë të shekullit XX (The family, religion, and customary law in Albania until the first half of the 2oth century)", Politika dhe Shoqëria, 1(11): 31-44.

King, R. (2003) "Across the sea and over the mountains: documenting Albanian migration", Scottish Geographical Journal, 119(3): 283-309.

King, R. (2005) "Albania as a laboratory for the study of migration and development", Journal of Southern Europe and the Balkans, 7(2): 133-56.

King, R. and Mai, N. (2008) Out of Albania: From Crisis Migration to Social Inclusion in Italy, Berghahn, Oxford, in press. 
Accepted Manuscript (AM) of Vullnetari, J. (2012) Women and migration in Albania: A view from the village. International Migration 5O(5): 169-188. [DOI: 10.1111/j.1468-

2435.2009.00569.x][accepted o8 September 2008; first published online 29 September 2009;

published 2012].

King, R., et al. (2003) Exploding the Migration Myths: Analysis and Recommendations for the European Union, the UK and Albania, The Fabian Society and Oxfam, London.

King, R. and Vullnetari, J. (2003) Migration and Development in Albania, Working Paper $\mathrm{C}_{5}$, Development Research Centre on Migration, Globalisation and Poverty, University of Sussex, Brighton.

King, R. and Vullnetari, J. (2006) "Orphan pensioners and migrating grandparents: the impact of mass migration on older people in rural Albania", Ageing and Society, 26(5): 783-816.

King, R. and Zontini, E. (2000) "The role of gender in the South European immigration model", Papers, Revista de Sociologia, 60: 35-52.

Lamani, M. (2003) Gratë në Kuvend (Women in the Parliament), Kuvendi i Shqipërisë. Sektori i Kërkimit dhe Biblioteka, Tirana.

Lazaridis, G. (2000) "Filipino and Albanian women migrant workers in Greece: multiple layers of oppression", in Anthias, F. and Lazaridis, G. (eds), Gender and Migration in Southern Europe, Berg, Oxford and New York, 49-79.

Levitt, P. and Glick Schiller, N. (2004) "Conceptualising simultaneity: a transnational social field perspective on society", International Migration Review, 38(3): 1002-39.

Logoreci, A. (1977) The Albanians. Europe's Forgotten Survivors, Victor Gollancz, London.

Mai, N. (2001) "Transforming traditions: a critical analysis of the trafficking and exploitation of young Albanian girls in Italy", in King, R. (ed.), The Mediterranean Passage: Migration and New Cultural Encounters in Southern Europe, Liverpool University Press, Liverpool, 258-78.

Mai, N. (2005) "The Albanian Diaspora-in-the-making: media, migration and social exclusion", Journal of Ethnic and Migration Studies, 31(3): 543-61. 
Accepted Manuscript (AM) of Vullnetari, J. (2012) Women and migration in Albania: A view from the village. International Migration 5O(5): 169-188. [DOI: 10.1111/j.1468-

2435.2009.00569.x][accepted o8 September 2008; first published online 29 September 2009;

published 2012].

Marcus, G. (1995) "Ethnography in/of the World System, the emergence of multisited ethnography", Annual Review of Anthropology, 24: 95-117.

Minnesota Advocates for Human Rights (1996) Domestic Violence in Albania, Minnesota Advocates for Human Rights, Minnesota.

Mitterauer, M. (1996) "Family contexts: the Balkans in European comparison", The History of the Family, 1(4): 387-406.

Moreno-Fontes Chammartin, G. and Cantú-Bazaldúa, F. (2003) Identification of Potential for Increasing Employment and Productive Investment in Albania, Moldova and Ukraine Based on Remittances, International Migration Papers 74, ILO, Geneva.

Musaj, F. (2002) Gruaja në Shqipëri, 1912-1939 (Women in Albania, 1912-1939), Akademia e Shkencave e Shqipërisë, Instituti i Historisë, Tirana.

Nicholson, B. (2004) "Negotiating the legacy of tradition: rural women's empowerment in Southern Albania", Electronic Journal of Polish Agricultural Universities. Economics series, 7(2).

Orgocka, A. (2005) "Albanian highly skilled women in the US", in King, R., et al. (eds), The New Albanian Migration, Sussex Academic Press, Brighton, 139-53.

Phizacklea, A. (ed.) (1983) One Way Ticket. Migration and Female Labour, Routledge and Kegan Paul, London.

Sampson, S. (1996) "The social life of projects, importing civil society in Albania", in Hann, C. and Down, E. (eds), Civil Society, Challenging Western Models, Routledge, London.

Schwandner-Sievers, S. (2006) "'Culture' in court: Albanian migrants and the anthropologist as expert witness", in Pink, S. (ed.), Applications of Anthropology. Professional Anthropology in the Twenty-First Century, Berghahn, Oxford, 209-32.

Sintès, P. (2003) Les Albanais en Grèce. Le rôle des réseaux préexistants, Balkanologie, 7(1): 111-33. 
Accepted Manuscript (AM) of Vullnetari, J. (2012) Women and migration in Albania: A view from the village. International Migration 5O(5): 169-188. [DOI: 10.1111/j.1468-

2435.2009.00569.x][accepted o8 September 2008; first published online 29 September 2009;

published 2012].

Sjöberg, Ö. (1992) Rural Change and Development in Albania, Westview Press, Oxford.

Tarifa, F. (2007) "Of mice, men and mountains: justice Albanian style", Sociological Analysis, 1(1): 89-124.

Tirta, M. (1999) "Migrime të shqiptarëve, të brendshme dhe jashtë atdheut: vitet '40 të shek.XIX-vitet '40 të shek.XX. (Migrations of Albanians within their homeland and abroad, between 1840s-1940s)", Etnografia Shqiptare, 18.

UNDP-Albania (1999) National Women Report Albania 1999, UNDP-Albania, Tirana.

UNDP-Albania (2005) Pro-Poor and Pro-Women Policies and Development in Albania. Approaches to Operationalising the Millennium Development Goals (MDGs) in Albania, UNDP, Tirana.

Vaiou, D. and Stratigaki, M. (2008) "From 'settlement' to 'integration': informal practices and social services for women migrants in Athens", European Urban and Regional Studies, 15(2): 119-31.

van Hear, N. (1998) New Diasporas, UCL Press, London.

Van Hook, M., et al. (2000) "Responding to gender violence in Albania. A partnership effort", International Social Work, 43(3): 351-63.

Van Hook, M., et al. (2006) "Sexual trafficking of women. Tragic proportions and attempted solutions in Albania", International Social Work, 49(1): 29-40.

Vertovec, S. (1999) "Conceiving and researching transnationalism", Ethnic and Racial Studies, 22(2): 447-62.

Vullnetari, J. (2007) Albanian Migration and Development. State-of-The-Art Review, IMISCOE Working Paper $<$ http://www.imiscoe.org/publications/working papers/documents/Albanianmigration.pdf $>$, Amsterdam.

Vullnetari, J. and King, R. (2008) '"Does your granny eat grass?' On mass migration, care drain and the fate of older people in rural Albania", Global Networks, 8(2): 139-71. 
Accepted Manuscript (AM) of Vullnetari, J. (2012) Women and migration in Albania: A view from the village. International Migration 5O(5): 169-188. [DOI: 10.1111/j.1468-

2435.2009.00569.x][accepted o8 September 2008; first published online 29 September 2009; published 2012].

Whitaker, I. (1981) "'A sack for carrying things': the traditional role of women in Northern Albanian society", Anthropological Quarterly, 54(2): 146-56.

World Bank (2006) Albania: Labour Market Assessment, Report 34597-AL, World Bank, Washington DC.

Young, A. (2000) Women Who Become Men: Albanian Sworn Virgins, Berg, Oxford.

Zinn, D. and Rivera, A. (1995) "Notes on a displaced womanhood: Albanian refugee women in Southern Italy", Anthropology of East Europe Review, 13(1): 23-29. 